\title{
Towards the assurance of transparency and quality of higher education in Ukraine: National Qualification Framework
}

\section{Iryna Skliar}

$\mathrm{PhD}$, Associate Professor, Department of Finance and Entrepreneurship, Oleg Balatsky Academic and Scientific Institute of Finance, Economy and Management, Sumy State University, Ukraine

\begin{abstract}
The attractiveness and transparency of higher education depends on complex of factors, which are based on quality assurance. The implementation of these procedures is based on national system of qualifications. The aim of the article is to provide the brief overview of changes in the higher education of Ukraine, especially progress in the implementation of the National Qualification Framework. The analysis of the higher education in Ukraine in dynamics according to indicators characterizing its attractiveness, show the deterioration of the situation. The article presents the analysis of the Plan of implementation of the National Qualification Framework for 2016-2020 in terms of recommendations given since the adoption of the National Qualification Framework by Ukrainian and European specialists in terms of European experience: implementation of the European Qualification Framework for lifelong learning.
\end{abstract}

Keywords: National Qualification Framework, higher education, learning outcomes, Ukraine, Higher education standards.

JEL Classification: A2, I2, I23.

(C) The Authors, 2018. This article is published with open access at Sumy State University.

\section{Higher education in Ukraine: analysis of attractiveness}

The system of higher education in Ukraine has gone a long way of development. There is some progress. The legislative framework has been developed: the National Qualification Framework (2011), the Law of Ukraine "On Higher Education" (2014). The process of institutionalization of quality assurance has begun - the National Agency for the Higher Education Quality Assurance has begun to work, projects of higher education standards have been developed. However, the current stage of the formation of the national education system is, in our opinion, decisive. At this stage, it is important to understand the positive results that have been achieved, and the most important is to clearly formulate miscalculations and "tight spots". The statistics show that they are. One of the most prominent indicators of the attractiveness of Ukrainian higher education is the number of Ukrainian students who prefer studying in their country. Despite the higher cost of education abroad, Ukrainians prefer education in other countries (Fig. 1). Recently, opportunities for education, work and educational mobility have expanded and students show the high exit activity.

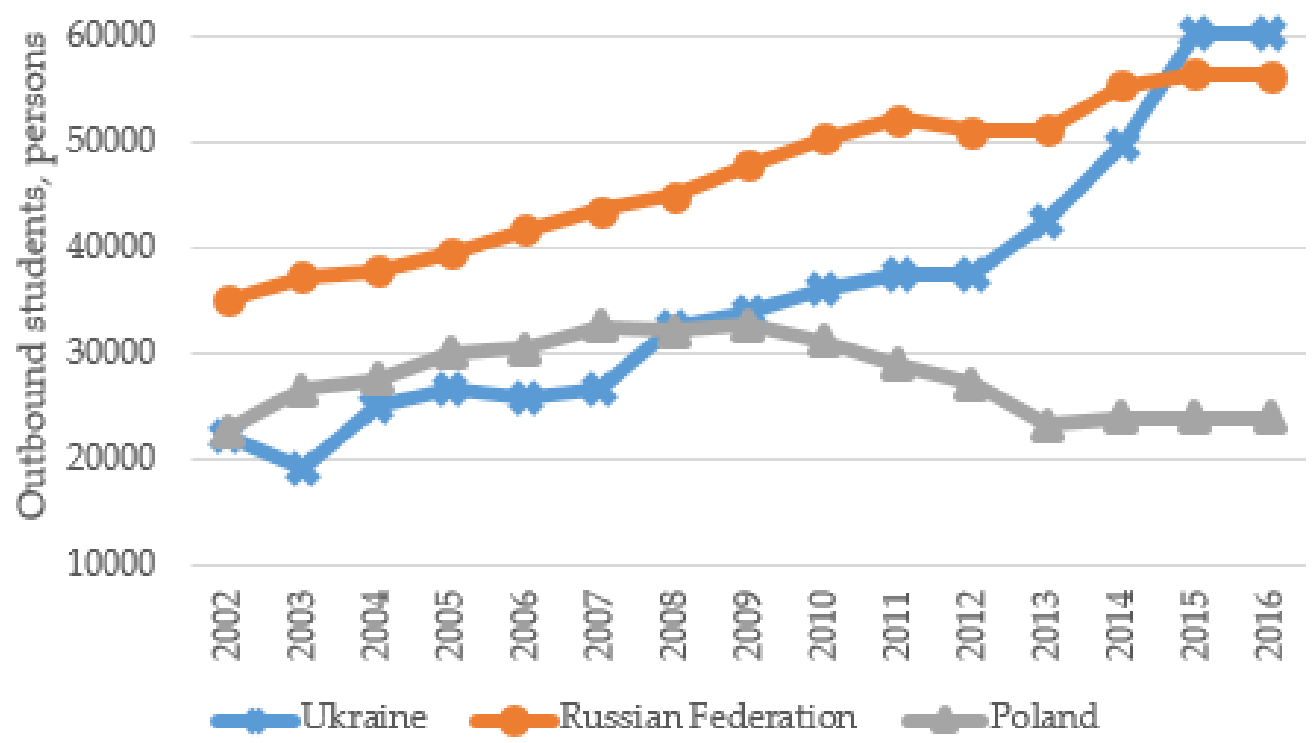

Figure. 1 Outbound internationally mobile students 
As shown in Figure 1, starting in 2011, the number of people leaving for higher education has increased significantly. Ukraine looks even worse concerning this issue than countries with a similar experience in reforming the higher education systems. Poland shows good progress on this issue. This country has been able to radically change the situation since 2010. HEIs in Poland offer over 400 English-language educational programmes (Bachelor, Master, $\mathrm{PhD}$ ) [9]. And at present, not only the number of students who leave Poland to study abroad decreases, but also the number of foreign students who wish to study in Poland increaes. In 2010 in Poland there were more people who left for studying abroad, while in Ukraine there was a slight excess of those who came over those who left (Fig. 2). And by 2014 Poland had already outrun Ukraine. And in 2016 the number of foreign students is 62054 persons (excluding Erasmus + programmes). Moreover, $53.5 \%$ of all foreign students are Ukrainians [9]. As we see in Figure 2, the United Kingdom has indeed created a powerful education system. Higher education in this country has become an export resource. According to the indicator of net flow of internationally mobile students, the United Kingdom almost 40 times exceeds Ukraine [8].

In Ukraine there is also a growing dynamics for the period 2010-2014 (Fig. 2). However, already in 2015 there is a negative value of 2741 persons [8]. This situation is explained by the orientation of Ukrainian students to studying abroad as well as the smaller inflow of foreign students to Ukraine.

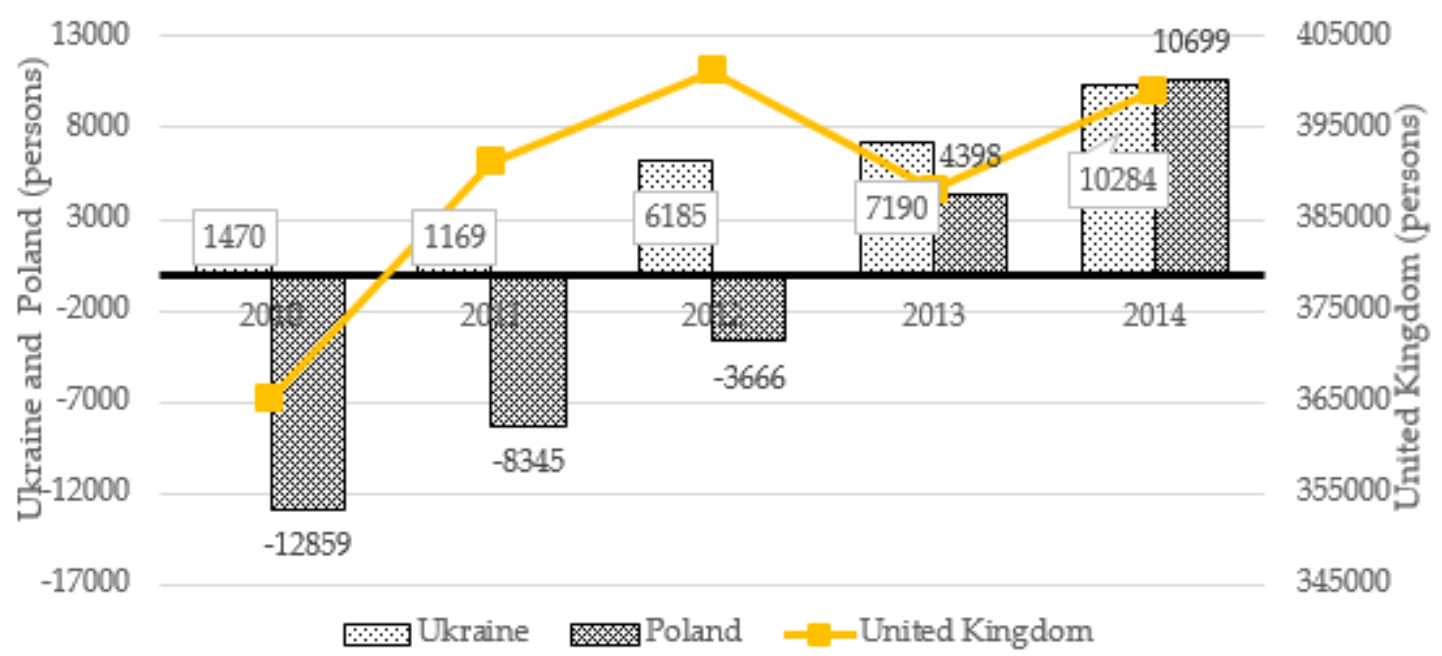

Figure 2. Net flow of internationally mobile students

The structure of the contingent of foreign students studying in Ukraine is indicative from the point of view of the development of higher education, improvement of quality assurance. Figure 3 shows that Ukrainian education is attractive mainly for citizens from countries with a transitory economy (Azerbaijan, Georgia, Turkmenistan, Uzbekistan) or from developing countries (India, Jordan, Egypt, Nigeria, Morocco, China).

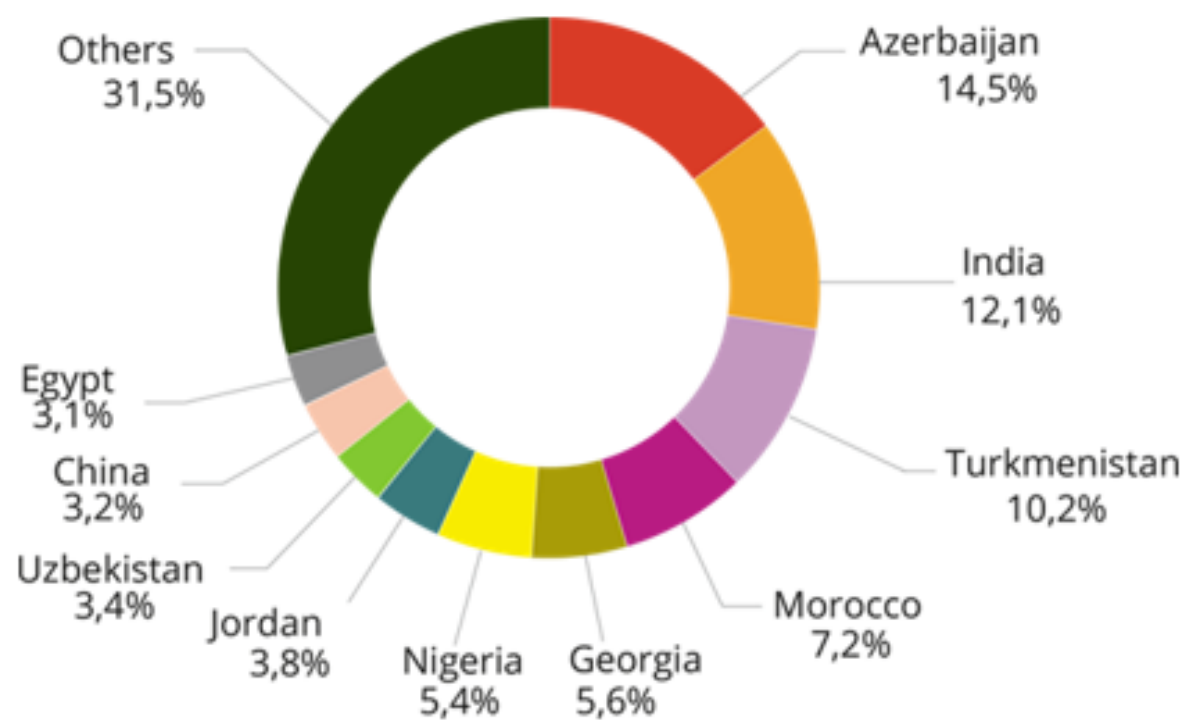

Figure 3. Structure of foreign students learning in Ukraine, 2016 [5] 
Despite the rather low cost of education, there is no significant increase in foreign students who have expressed the desire to study in Ukraine. Obviously, this situation is caused by many reasons: political instability in the country, economic situation, military actions and other risks. However, in terms of determining further actions for the reform of higher education, it is important to study in detail only one factor: the progress of the education system itself. It is now necessary to answer the question: how much the changes in the system of higher education have made real progress in order to increase the attractiveness of Ukrainian higher education? What components of the national qualification system do not work and why? And what tasks should be solved today at the national and institutional level to change the situation?

\section{Changes in the Ukrainian system of higher education, their impact}

The process of developing the National Qualification Framework in Ukraine was initiated by the Order of the Ministry of Education and Science of Ukraine No. 602 of July 3, 2008. It was officially approved by the Cabinet of Ministers of Ukraine, Resolution No. 1341 of 23.11.2011 [7]. The main characteristics of the Ukrainian National Qualification Framework:

$>$ qualifications are described in terms of learning outcomes for each educational level;

$>$ contains 4 descriptors (knowledge, skills, communication, autonomy and responsibility) and integral competence;

allows to coordinate qualifications.

The place of the National Qualification Framework in the National Education Area is determined by the tasks that it has to solve:

$>$ to ensure greater transparency of the national education system, the importance of its qualifications;

$>$ to ensure the unity of the system, the relationship between its levels, coordination;

$>$ to promote the continuity of educational programmes based on the ideology of lifelong learning;

$>$ to promote the recognition of knowledge, skills and competences acquired through nonformal / informal learning;

$>$ to create the tool for ensuring the alignment of educational institutions to external and internal quality requirements;

to increase the relevance of education and training for society;

$>$ to promote international mobility (of workers, students) by comparing national qualifications with qualifications of other countries.

An Action Plan was developed to implement the National Qualification Framework. This document contained a list of other normative legal acts / orders that need to be developed to ensure full implementation of the National Qualification Framework. It was planned 17 events for 2012-2015. However, in fact, this plan was not implemented for a number of reasons. The main thing is the political changes in the country and the adoption of the new Law of Ukraine "On Higher Education" from 06.09.2014 [6].

This law has significant differences from the previous one:

$>$ academic autonomy. Each HEI has the right to form and implement its own educational and research programmes, and therefore the obligation to ensure the quality of education upon these programmes. This requires a significant change in the approaches to the organization of the educational process;

$>$ new requirements for the quality assurance system at the national and institutional levels;

$>$ independent procedures for assessing the quality of higher education, which essentially introduces competitive principles in the market of educational services;

$>$ change of the defined format of higher education standards.

All these innovations require a radical change in the environment of higher education in Ukraine. These changes should begin with the actual implementation of the National Qualification Framework. Understanding this, the Government of Ukraine approves the Action Plan for the implementation of the National Qualification Framework for 2016-2020 from 14.12.2016 [1]. However, a number of questions arise as to the completeness of a specific list of tasks. For the past six years, the National Qualifications Framework has been adopted. During this period, the experience of using the National Qualification Framework has been accumulated. A number of European projects concerning the implementation of the National Qualification Framework have been implemented. Thus, a detailed analysis of the National Qualification Framework was carried out within the framework of the Twinning project "Development of standards for vocational technical education taking into account the descriptors of the levels of the National Qualification Framework" in 2013. We examined in 
detail the expert opinion on the Ukrainian National Qualification Framework (Hanf, Georg, 2013) the views of other experts ${ }^{1}$, and analyzed the actions that have been taken over the past three years. Summarizing all this we highlighted the shortcomings and deficiencies associated with the National Qualification Framework and the process of its implementation.

1. National Qualification Framework is just as a tool for qualification classification, but not as a tool for comparing them. The framework itself is a useful tool for increasing the transparency of the qualifications system, but in this context, reform processes and their impact on the evaluation, awarding and certification of qualifications are much more important. That is, we are talking about not only the classification and comparison of qualifications (ESG, 2015: 9). Even as an instrument for classifying the existing qualifications the National Qualification Framework is not used. The main reason for this is the lack of a procedure for "official" correlation and allocation of qualifications by the levels of the framework (Hanf, Georg, 2013: 17-18).

2. Functional limitations of the National Qualification Framework. The emphasis is on the fact that "The Resolution of the Cabinet of Ministers of Ukraine determines what the frame will be used for, but does not prescribe how it will be used. Consequently, the Ukrainian National Qualification Framework can be characterized as a rather "free" framework" (Hanf, Georg, 2013: 11). Among such functional problems, particular attention is paid to the fact that there are no defined tasks related to access, transfer, continuity of learning, recognition of learning outcomes acquired as a result of nonformal / informal learning. It is also not about the responsibility of educational institutions (qualification providers) for the quality (process and results) of educational services provided by them. As the expert points out, "it seems like "lifelong learning", which underlies the European Qualification Framework, is not an important part of the Ukrainian National Qualification Framework" (ESG, 2015: 10). It is also not defined how the process of interaction between different levels of education within the qualification system will take place and how the Ministry of Education and Science of Ukraine and the Ministry of Social Policy of Ukraine will communicate and cooperate. This issue needs to be finalized in other documents (Hanf, Georg, 2013: 11).

3. Lack of principles and procedures for the inclusion of qualifications in the National Qualification Framework. These principles and procedures are mandatory, without them the National Qualification Framework functions as a tool for ensuring the unity of the education system and its transparency. Procedures for including qualifications in the National Qualification Framework should be implemented along with the matching procedure, which allows to associate particular qualifications with a certain level of the framework. Comparison means checking the alignment of qualification (type) with descriptors of learning outcomes of a certain level. Thus, the transparency of the qualification system for all types of qualifications is achieved, and the links between qualifications become clearer. To provide these procedures, it was proposed to create a manual with instructions for the future allocation of qualifications, as well as register of qualifications (Hanf, Georg, 2013: 21).

4. The problem of common language. National Qualification Framework should provide a common language for all stakeholders - the language of learning outcomes. Experts emphasize the need for a clear, consistent, approved terminology. Such a conclusion is made on the basis of analysis of official Ukrainian documents (Regulations on the approval of the National Qualification Framework and other regulations), where there is "certain inconsistency" (Hanf, Georg, 2013: 12). Approval of terminology, its harmonization is an obligatory element of the process of implementation of the National Qualification Framework. This terminology should become the language of official documents. To achieve this it was suggested: 1) to create an integrated glossary (Hanf, Georg, 2013: 13, 19) based on which to review documents related to the implementation of the National Qualification Framework, 2) a website of the National Qualification Framework, which would include information for all stakeholders and contributed to the clarification of qualifications, their connection, recognition, etc.

5. Learning outcomes in the educational process. The lack of a learning outcomes mechanism makes it impossible to fully implement the National Qualification Framework. The European Qualification Framework recommendation makes clear that the qualification to be included in the framework should be described in the categories of learning outcomes. Most existing qualifications in Ukraine do not have such a description. Consequently, it is doubtful whether they should be compared with the National Qualification Framework and included in it (Hanf, Georg, 2013: 21). A number of decisions should be taken: What qualifications should be included? Who will make a comparison? How to do this?

${ }^{1}$ Ukrainian-Polish project "Innovative University and Leadership", TEMPUS ALIGN project "Achieving and checking the alignment between academic programmes and qualification frameworks" 
6. Change in approaches to teaching (Hanf, Georg, 2013: 7). Not only teaching methods need to be changed. Implementation of the approach based on learning outcomes is a task that involves a set of procedures that need to be changed or improved at the institutional level (HEI-level).

7. The problem of administration and coordination. According to G. Ganf, "Ukrainian National Qualification Framework is developed as a comprehensive framework that includes all qualification sectors: general education, vocational education, higher education, (future) professional qualifications. To unite all sectors "in one", an appropriate management / administration structure is needed (Hanf, Georg, 2013: 24).

Consequently, it can be stated that there is currently no progress in the implementation of the National Qualification Framework in Ukraine. As a confirmation, let's quote G. Ganf "at the moment, the Ukrainian National Qualification Framework as a qualification classification tool is similar to an empty shelf of 10 levels, with 4 divisions at each level. Qualifications are not yet officially distributed" (Hanf, Georg, 2013: 21). From the moment of this statement in this area, nothing has changed de facto. On the contrary, the list of tasks expanded and complicated with the adoption of the Law of Ukraine "On Higher Education". Recognizing this, the Cabinet of Ministers of Ukraine approved the Action Plan for the Implementation of the National Qualification Framework for 2016-2020, Order No. 1077-p of December 14, 2016. The question is: How effective and useful the implementation of the National Qualification Framework will be according to this plan? Are remarks made by European experts and Ukrainian specialists taken into account?

\section{Action Plan for the implementation of the National Qualification Framework for 2016-2020: perspectives and challenges}

The plan provides 25 events within 7 generalized blocks (Table 1 - see Appendix). It is obvious that much work has been planned on the implementation of the National Qualification Framework, a lot of recommendations have been taken into account when drafting this document. However, a number of questions arise as to the sequence of proposed measures, as well as to their completeness and content. We will try to analyze the proposed Plan for the implementation of the National Qualification Framework for 2016-2020 in two contexts: 1) in the context of recommendations for the removal of shortcomings that have been expressed since the adoption of the National Qualification Framework by Ukrainian and European experts and tasks defined by the Law of Ukraine "On Higher Education", and 2) in the context of European experience: implementation of the European Qualification Framework for lifelong learning.

A detailed analysis of the Action Plan gives grounds for highlighting such remarks.

Events are not always consistent in time. As of 2016, when the Plan was approved, there has already been an understanding of certain omissions in the National Qualification Framework itself. Logically, it would be a start-up step to determine exactly how to make changes to the current edition of the National Qualification Framework, and to plan all subsequent measures based on the updated content. Herewith the current Plan provides the revision of the National Qualification Framework in 2020. In addition, the main contradiction lies in our view in Action 22 "Alignment of the National Qualification Framework to the EQF LLL", the actual measure as it is, and the term for its implementation - 2018-2020. For 2018-2019 the task is "to conduct the analysis of the alignment of the National Qualification Framework with the criteria of the European Qualification Framework for lifelong learning". If the results of the analysis reveal misalignment (and this is likely because there are already some discrepancies in the information available), how can one explain that by the moment other tasks provided by the Plan have already to be completed? Such inconsistency makes it difficult to carry out current tasks, Their implementation will be based on the current edition of the National Qualification Framework. In particular, the standards of higher education currently under development must be consistent with learning outcomes of the National Qualification Framework. Upon completion of this complex, longstanding and important work in terms of establishment of the national system of qualifications, the issue of alignment of standards with the basic document of the National Qualification Framework will be raised.

Common Speech. In our opinion, a rather urgent task to be solved through the implementation of the National Qualification Framework is not fully resolved when developing the Action Plan. European experts who work in Ukraine on projects of the European Commission ${ }^{2}$. emphasize on the terminological inconsistency. The terminological inconsistency with the adoption of the Law of Ukraine "On Higher Education" has not decreased, but rather increased. The definition of basic concepts of learning outcomes and competencies in the 
National Qualification Framework ${ }^{3}$ and the $\mathrm{Law}^{4}$ is different. The Action Plan doesn't provide creating an integrated glossary, which was recommended.

Administration and coordination remain relevant. The reestablishment of the Interdepartmental work group does not solve the issue of a permanent coordinating structure. The creation of a subcommission within the framework of the Scientific and Methodological Commission 15 of the Ministry of Education and Science of Ukraine also does not fully solve this issue, since this commission has in fact no regulatory powers. In some countries, institutions have been set up to support the implementation of the National Qualification Framework, as a rule, National coordination points. The list of tasks faced by these institutions is quite broad from coordination (if only National Qualification Framework functions as a means of ensuring transparency, providing communications of the stakeholders) to ensuring quality, recognizing results of nonformal and informal learning, as well as the development of new professional standards and qualifications of vocational education (Hanf, Georg, 2013: 24).

Need for procedures of partial qualification recognition. This task should also be solved in the process of implementing the National Qualification Framework. Among the planned list, we have not found the task of developing the recommendation for partial recognition of qualifications. Meanwhile, it is provided by recommendations for the implementation of EQF LLL.

Parallel development of Learning outcomes-based instruments. The experience of implementing the EQF shows that the effectiveness of this process depends on the parallel development of Learning outcomes-based instruments, in particular ECTS, ECVET - The European Credit system for Vocational Education and Training, and the European key competences framework). The Action Plan does not provide anything for the development of these tools.

In addition to these omissions, we especially want to emphasize the main, as we consider, task of introducing the National Qualification Framework - reorienting the educational process to the learning outcomes and thereby causing a change in pedagogical approaches. National Qualification Framework form the basis on which the whole complex of processes should be built (Fig. 4). It creates boundaries, but the educational process is implemented at the basic level - at the level of a specific educational programme. And the real process of implementing the National Qualification Framework takes place at the level of a specific educational programme.

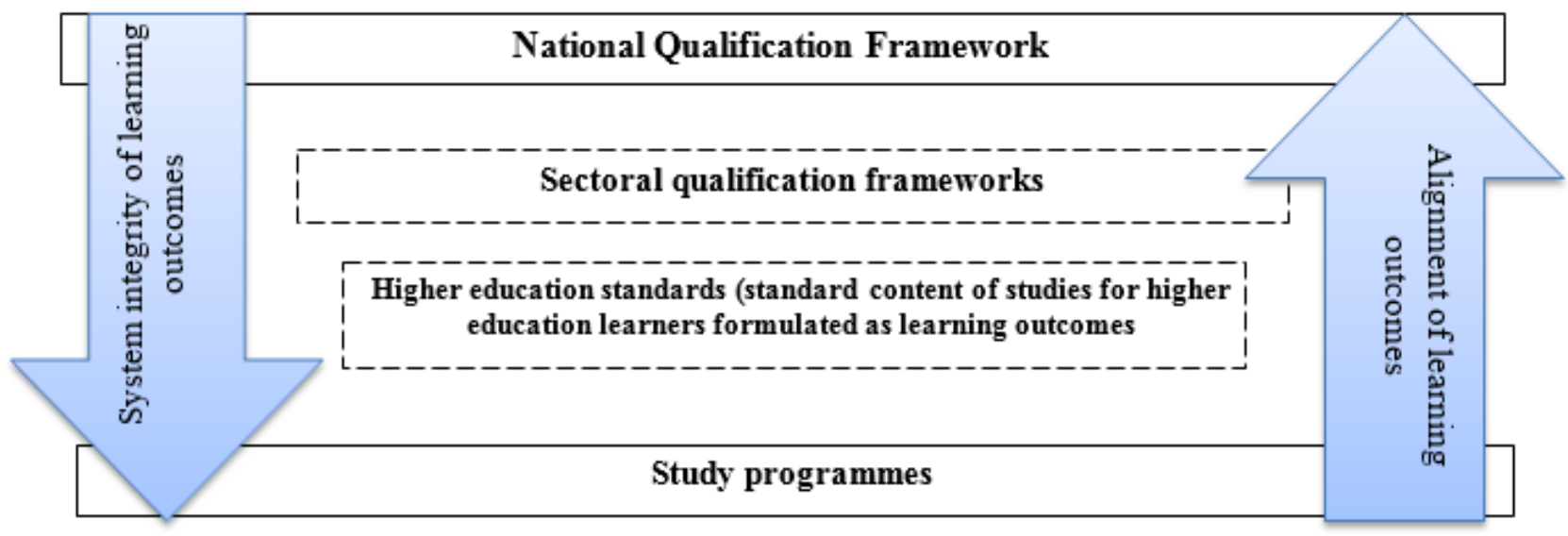

Is currently in the process of development

Figure 4. Alignment of learning outcomes

\footnotetext{
${ }^{3}$ National Qualification Framework: learning outcomes - competencies (knowledge, understanding, skills, values, other personal qualities) that a person acquires and / or is able to demonstrate upon completion of training;

competence / competences - the ability of a person to perform a certain type of activity, expressed through knowledge, understanding, skills, values, other personal qualities.

${ }^{4}$ Law of Ukraine on Higher Education, art. 1: learning outcomes shall mean an aggregate of knowledge, abilities, skills and other competencies that students have attained in a set of educational experiences under a particular vocational or academic programme which may be identified, numerically assessed and measured;

competency shall mean a dynamic combination of knowledge, abilities and practical skills, thinking patterns, professional, world-conceptualizing and civic qualities, moral and ethical values that defines an individual's capability to successfully engage in professional activity and further learning and is a result of learning at a particular level of higher education.
} 
The need for changing teaching and learning methods, rethinking approaches to assessment is now extremely urgent. The renewal of the chain "teaching - learning - assessment", which is the basis of the Student-Centered Learning, is urgently needed. The main ones in this list are the change in teaching methods (changes on the part of the teacher), learning methods (changes on the part of the student), assessment (mutual changes of both parts). There is a need to reorient to active learning, in which students solve problems, answer questions, formulate questions on their own, discuss, explain, debate and carry out brainstorming during the lesson. It is important to have joint training when students work in teams to solve a problem, to implement a project in conditions that ensure both positive interdependence and individual responsibility, as well as the development of inductive learning methods (learning based on situation analysis, problem-based learning, etc.)

Regarding the assessment. It is important not only to change the assessment methods. It is necessary to change the concept of assessment. Assessment is the center of the educational process in the student-centered model. Effective assessment necessarily implies:

$>$ assessment is at the center of the programme development;

$>$ feedback is used to improve student learning;

$>$ students and teachers have become responsible partners in learning and assessment;

$>$ students are introduced into the practice and culture of higher education concerning assessment;

$>$ use to identify what is most productive for students in the learning process;

$>$ assessment for learning is a guideline for staff and institutional development;

$>$ assessment provides a comprehensive and accurate picture of student achievement.

Without this, one cannot hope for the full implementation of the National Qualification Framework and the consequences that it must carry.

\section{Conclusions and recommendations}

It is possible to ensure the transparency in the higher education system only if the National Qualification Framework is implemented. We believe that the implementation of the National Qualification Framework cannot be without significant shifts at the level of Higher Education Institutions. We suppose that to ensure the effectiveness of the implementation of the National Qualification Framework it is necessary to structure the tasks - to identify separately the tasks relating to the national level, separately those whose solution relates to the authorities of higher education institutions. Obviously, performance can only be achieved by combining the tasks of both groups.

It is necessary to plan the broad advisory, educational work, at least for members of project groups and guarantors of educational programmes. There should be a wide list of events, workshops, trainings, etc. In the future, it is necessary to prepare a pool of experts (Peer-review experts) from Ukrainian higher education specialists to disseminate good practices and experience of the leading European universities in disseminating learning-outcomes approach, recognition of qualifications, and in the future, participation in external quality assurance procedures in accordance with standard 2.4. Peer-review experts (Standards and Guidelines for Quality Assurance in the European Higher Education Area (ESG), 2015) There is a positive experience of such training. So, within the project "Innovation University and Leadership" a lot of people took part in the training. They are currently not only active in the educational process of their own institutions, but also work at the national level.

The implementation of the National Qualification Framework needs to be considered in a wider context, since the basic aim of its implementation is to promote the mobility of workers and students through the comparability of qualifications and the transparency of their assignment procedures. The implementation of the National Qualification Framework should come from understanding that Education and training policies are central to the Europe 2020 Strategy as it is acknowledged that the "way to go out of the crisis must mean moving to a more competitive economy, which is knowledge based, inclusive and sustainable, giving good employment opportunities for women and men" [3].

EU 2020 Strategy [2] recognises investment in education and trainingas a priority in order to achieve its main aim of accelerating economic recovery in Europe. "Youth on the Move" and "An Agenda for New Skills and Jobs" are the two (out of seven) flag ship initiatives under EU 2020 that are most pertinent to education, training and qualifications:

Youth on the Move aims to 'unleash the potential of young people to achieve smart, sustainable and inclusive growth in the European Union'. It underlines the need for intertwined cooperation between 
education and training policies, while aiming to increase the share of citizens with tertiary or equivalent qualifications.

The Agenda for New Skills and Jobs prioritises 'flexicurity' and places emphasis on the role of education and employment policies, both separately and combined, in addressing the adverse impact of the economic crisis on employment and insecuring growth and competitiveness in the long term by effectively matching skills to jobs.

It is necessary to provide the National Qualification Framework with the status of a truly basic document in the process of assessment, classification and recognition of qualifications. All legislative and regulatory frameworks must be consistent with the National Qualification Framework.

\section{References}

1. Action Plan for implementation of the National Qualification Framework in 2016-2020. Approved by the Order of the Cabinet of Ministers of Ukraine of December 14, 2016 № 1077. Available at phttp://zakon2.rada.gov.ua/laws/show/1077-2016-\%D1\%80/conv/print1478789915348654.

2. EUROPE 2020. A European strategy for smart, sustainable and inclusive growth. Available at http://ec.europa.eu/eu2020/pdf/COMPLET\%20EN\%20BARROSO\%20\%20\%20007\%20-\%20 Europe \%202020\%20-\%20EN\%20version.pdf.

3. Evaluation of the Implementation of the European Qualifications Framework Recommendation Final report 17 October 2013. Available at https://ec.europa.eu/ploteus/sites/eac-eqf/files/DG\%20EAC\%20\%20Evaluation\%20EQF\%20-\%20Final\%20Report\%20-\%20Final\%20Version.pdf.

4. Hanf, Georg (2013). "Implementation of the National Qualification Framework: Current state and future perspectives - document with the description of possible variants" Project Twinning, Ukraine, UA11/ENPPCA/SO33 "Modernization of legislative standards and principles of education and learning according to the EU policy as to lifelong learning - Project of November 30, 2013. Available at http://ipq.org.ua/upload/files/files/03_Novyny/2015.03.18_Twinning_final conference /NQF\%20Implementation\%20-\%20State\%20of\%20the\%20art\%20and\%20outlook.\% 20Optional \%20paper_UKR.pdf.

5. International students in Ukraine. Available at http://studyinukraine.gov.ua/life-in-ukraine/internationalstudents-in-ukraine/.

6. Law of Ukraine "On Higher Education" (2014) (English). Available at http://erasmusplus.org.ua/vyshchaosvita-v-ukraini.html.

7. National Qualification Framework. Resolution of the Cabinet of Ministers of Ukraine of November 23, 2011 № 1341. Available at http://zakon3.rada.gov.ua/laws/show/1341-2011-\%D0\%BF.

8. Net flow of internationally mobile students. Available at http://uis.unesco.org/indicator/edu-mobility-

9. Over 65,000 foreign students in Poland. Available at http://www.studyinpoland.pl/en/index.php/news/71over-65-000-foreign-students-in-poland.

10.Recommendation of the European Parliament and of the Council of 23 April 2008 on the establishment of the European Qualifications Framework for lifelong learning. Official Journal of the European Union. 6.5.2008. Available at http://eur-lex.europa.eu/legal-content/EN/TXT/PDF/?uri=CELEX: 32008H0506(01)\&from=EN.

11.Standards and Guidelines for Quality Assurance in the European Higher Education Area (ESG) Approved by the Ministerial Conference in Yerevan, 14-15 May 2015. Available at http://www.britishcouncil.org.ua/sites/default/files/standards-and-guidelines_for_qa_in_the_ehea 2015.pdf. 


\begin{tabular}{|c|c|c|}
\hline Task & The content of the task & Execution period \\
\hline \multicolumn{3}{|c|}{ Coordination of work and normative-legal support for the formation and development of the National Qualification System } \\
\hline $\begin{array}{l}\text { 1. Identifying and ensuring the participation of all stakeholders in the implementation } \\
\text { of the National Qualification Framework }\end{array}$ & $\begin{array}{l}\text { renewal of work of the Interdepartmental work group on the development and implementation of the National } \\
\text { Qualification Framework }\end{array}$ & December 2016 \\
\hline \multirow[t]{3}{*}{$\begin{array}{l}\text { 2. Development of a regulatory framework for the functioning of the National } \\
\text { Qualification System }\end{array}$} & $\begin{array}{l}\text { carrying out the analysis of legislation and drafting proposals for legislative support for the formation of the } \\
\text { National Qualification System }\end{array}$ & $2016-2017$ \\
\hline & $\begin{array}{l}\text { drafting and making appropriate changes to the legislation necessary for the implementation of the norms and } \\
\text { provisions of the National Qualification System and the National Qualification Framework }\end{array}$ & 2017 \\
\hline & $\begin{array}{l}\text { identifying the needs and opportunities (personnel, functional) of stakeholders and developing the proposals to } \\
\text { ensure their participation in the implementation of the National Qualification Framework and the National } \\
\text { Qualification System }\end{array}$ & 2016-2017 \\
\hline \multirow{2}{*}{$\begin{array}{l}\text { 3. Determining the role and responsibilities (functions) of all parties, bodies and } \\
\text { organizations interested in participating in the formation and development of the } \\
\text { National Qualification System }\end{array}$} & $\begin{array}{l}\text { preparation of regulatory acts and recommendations for the development, approval and revision of professional } \\
\text { standards }\end{array}$ & 2016-2017 \\
\hline & $\begin{array}{l}\text { preparation of regulatory acts and recommendations for the development and approval of qualifications, } \\
\text { educational standards, educational programmes of higher and vocational education }\end{array}$ & 2017 \\
\hline $\begin{array}{l}\text { 4. Periodic review of the National Qualification Framework in accordance with the } \\
\text { needs of economic and society development,, requirements of the Common European } \\
\text { Qualification Framework }\end{array}$ & $\begin{array}{l}\text { creating the mechanism for periodic review of the National Qualification Framework, updating its descriptors, } \\
\text { levels and structure }\end{array}$ & 2020 \\
\hline \multicolumn{3}{|c|}{ Modernization of the system for forecasting the need for qualifications and development of professional standards } \\
\hline 5. Development of the system for forecasting the need for qualifications & $\begin{array}{l}\text { modernization of tools for monitoring research on the real employment of graduates of higher and vocational } \\
\text { education institutions }\end{array}$ & 2016-2017 \\
\hline $\begin{array}{l}\text { 6. Adaptation of the National System of Classification of Professions (occupations) to } \\
\text { the International Standard Classification of Occupations (ISCO-08) }\end{array}$ & $\begin{array}{l}\text { development and approval of a new edition of the national classifier ДК 003: "Classifier of Occupations", which } \\
\text { corresponds to the International Standard Classification of Occupations (ISCO-08) }\end{array}$ & 2018-2019 \\
\hline 7. Creating the electronic register of professions & creating the electronic register of professions & $2018-2019$ \\
\hline \multirow{3}{*}{ 8. Development / updating and approval of professional standards } & development / updating of qualification characteristics / professional standards & 2016-2020 \\
\hline & $\begin{array}{l}\text { development / revision and approval of professional standards, providing trainings of professional standards } \\
\text { developers }\end{array}$ & 2016-2020 \\
\hline & creation of the register/ database of professional standards & 2017 \\
\hline \multicolumn{3}{|c|}{ Development of qualifications of different types (educational standards and programmes based on learning outcomes) in accordance with the National Qualification Framework } \\
\hline \multirow{2}{*}{$\begin{array}{l}\text { 9. Development and implementation of the National Register of Qualifications, which } \\
\text { are officially included in the National Qualification Framework (Register of the } \\
\text { National Qualification Framework) }\end{array}$} & $\begin{array}{l}\text { development of the Procedure for the inclusion of qualifications in the Register of the National Qualification } \\
\text { Framework }\end{array}$ & -"- \\
\hline & $\begin{array}{l}\text { preparation and implementation of approbation of methodological recommendations for comparison of } \\
\text { qualifications of different types according to the levels of the National Qualification Framework }\end{array}$ & 2017 \\
\hline \multirow[t]{2}{*}{$\begin{array}{l}\text { 10. Development of educational standards and programmes based on a competent } \\
\text { approach / learning outcomes }\end{array}$} & $\begin{array}{l}\text { development / updating of methodological recommendations for the establishment of higher education } \\
\text { programmes based on the competence approach / learning outcomes }\end{array}$ & 2016-2017 \\
\hline & $\begin{array}{l}\text { development / updating of methodical recommendations on the creation of educational standards and } \\
\text { programmes of vocational education in accordance with the competence approach }\end{array}$ & -"- \\
\hline $\begin{array}{l}\text { 11. Development / updating and approval of standards and educational programmes } \\
\text { in higher education }\end{array}$ & $\begin{array}{l}\text { development and approval of higher education standards for all levels of higher education (level 5-8 of the } \\
\text { National Qualification Framework), providing support to higher education institutions in developing } \\
\text { programmes at different levels of higher education, including training their developers }\end{array}$ & $2017-2019$ \\
\hline \multirow{3}{*}{$\begin{array}{l}\text { 12. Development / updating and approval of standards and educational programmes } \\
\text { of vocational education }\end{array}$} & updating the list of specialties of vocational education & $2016-2017$ \\
\hline & $\begin{array}{l}\text { development / updating the vocational education standards for qualifications of the level } 5 \text { of the National } \\
\text { Qualification Framework and training their developers }\end{array}$ & $2017-2020$ \\
\hline & $\begin{array}{l}\text { development / revision of standards and programmes of vocational education for qualifications of the level 3-4 } \\
\text { of the National Qualification Framework and training their developers }\end{array}$ & $2017-2020$ \\
\hline
\end{tabular}

6. Adaptation of the National System of Classification of Professions (occupations) to the International Standard Classification of Occupations (ISCO-08)

7. Creating the electronic register of profession

\begin{tabular}{l} 
development / updating of qualification characteristics / professional standards \\
\hline $\begin{array}{l}\text { development / revision and approval of professional standards, providing trainings of professional standar } \\
\text { developers }\end{array}$ \\
\hline
\end{tabular} creation of the register / database of professional standard

Qf of the Interdepartmental work group on the development and implemen

carrying out the analysis of legislation and drafting proposals for legislative support for the formation of the provisions of the National Qualification System and the National Qualification Framework

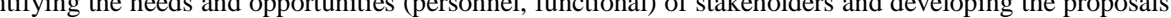

educational standards, educational programmes of higher and vocational education

or forecasting the need for qualifications and development of professional standards

modernization of tools for monitoring research on the real employment of graduates of higher and vocational $2016-2017$

development of the Procedure for the inclusion of qualifications in the Register of the National Qualification Framework qualifications of different types according to the levels of the National Qualification Framework programmes of vocational education in accordance with the competence approach

National Qulifiction Framerk), providing programmes at different levels of higher education, including training their developers

updating the list of specialties of vocational educatio

Qualification Framework and training their developers

of the National Qualification Framework and training their developer 
13. Development / revision and approval of standards and educational programmes of primary and complete secondary education

14. Development and approval of standards and programmes for vocational training

of adults by workers' professions (based on professional standards)

15. Development of standards for qualifications in occupations where advanced training and / or certification are required by law (regulated professions)

Development of the system of confirmation of

16. Development of the mechanism / methodological basis for recognition of the informal vocational learning outcomes

17. Development and approval of standards / assessment criteria in order to recognize the informal vocational learning outcomes

18. Aligning the system of quality assurance in higher education with European standards and guidelines for quality assurance in higher education (ESG)

19. Aligning the system of quality assurance in vocational education with European guidelines (EQAVET)

20. Aligning the educational programmes of higher and vocational education with the requirements of professional standards / professional qualifications (if available)

Improvement of the informat

21. Creation of the effective system of stakeholders' informing on the National Qualification Framework / National Qualification System

Ensuring international recognition of the National Qualification Framework and Ukrainian Qualifications

22. Aligning the National Qualification Framework with the criteria of the European Qualification Framework for lifelong learning

23. Aligning the National Qualification Framework with the criteria of the Qualification Framework of the European Higher Education Area

24. Ensuring official use of information on the National Qualification Framework in the annexes to the documents on higher and vocational education

25. Ensuring use of the National Qualification Framework as a tool for recognition of vocational education in accordance with European recommendations

\section{Qualification System}

updating standards and educational programmes of primary and complete secondary education

development of regulations on professional training in modular training programmes

2017

development / revision and approval of standards for qualifications of the level 3-7 of the National Qualification Framework for regulated professions, providing support to professional / specialist associations for the development of qualifications (level 3-7 of the National Qualification Framework), including training of mation of the professional learning outcomes (awarding the professional qualifications)

creation / updating of methodological support for the development of assessment criteria, means of measurement for the recognition of the informal vocational learning outcomes

Tevelopment of standards / assessment criteria in order to recognize the informal vocational learning outcomes according to qualifications of the level 2-5 of the National Qualification Framework

rovement of the processes of qualification quality assurance

act approval of requirements for accreditation of educational programmes of higher education organization of the sysen
requirements of ESG

development / updating of requirements for accreditation of educational programmes / vocational schools

organization of the system of internal quality assurance of vocational schools in accordance with the requirements of EQAVET

providing the assessment / accreditation (certification) of educational programmes of higher and vocationa education to conform the training of specialists / workers to the requirements of professional standards / professional qualifications

on system on the state of implementation of the National Qualification Framework

providing information about various ways of obtaining qualifications, including the possibility of confirming the encomes

ensuring the capacity building of interested organizations in methodological and informative work on the issues of the National Qualification Framework / National Qualification System

holding information campaigns, seminars, round tables, media conferences to raise awareness of pupils, students, academics, teachers, parents,

National Qualification System European Qualification Framework for lifelong learning we with the criteria of the European Qualification Framework for lifelong learning

preparation and publication of the report on self-certification with the participation of international experts

conducting the analysis of the alignment of the National Qualification Framework with the criteria of the Qualification Framework of the European Higher Education Area

development and implementation of measures to ensure the alignment of the National Qualification Framework with the criteria of the Qualification Framework of the European Higher Education Area

preparation and publication of the report on self-certification with the participation of international experts

updating information on the national education system, requirements for annexes to the documents on higher and

preparation of legal acts and recommendations on the use of the National Qualification Framework in the process of recognition of foreign qualifications in Ukraine
$2017-2020$

2017

2017

$2017-2020$

2017

$2017-2020$

-"-

2016-2020

2016-2020

$-"-$

$2017-2020$

$2018-2019$

2019-2020

2020

2018-2019

$2018-2020$

2020

2018-2020

2018-2020 